\title{
EVALUATION OF QUALITY OF LIQUID ORGANIC FERTILIZER FROM RABBIT'S URINE WASTE FERMENTED USING LOCAL MICROORGANISMS AS DECOMPOSERS
}

1M. I. Said* 1A. Asriany 1 S. N.Sirajuddin 1E. Abustam1R. Rasyid 2A.R.M. Al-Tawaha Assos.Prof Assis. Prof Assos.Prof. Prof . Researcher Researcher 1Faculty of Animal Science, Hasanuddin University

Jl. Perintis Kemerdekaan Km. 10 Macassart, South Sulawesi, Indonesia 90245

2Department of Crop Science, Faculty of Agriculture, University Putra Malaysia, 43400 UPM Serdang, Selangor, Malaysia irfan.said@unhas.ac.id irfanunhas@gmail.com

\section{ABSTRACT}

Rabbit's urine waste (RUW) is one of the by-products of rabbit metabolism that not utilized. The complex nutrient content of rabbit's urine is an enormous potential as a basic ingredient of liquid organic fertilizer (LOF). In the production process of LOF, the fermentation process becomes very important. In the fermentation process, the role of decomposer is very important. The use of commercial decomposers (CD) containing selected microorganisms is difficult to implement in rural areas, as they are expensive and difficult to obtain. Therefore, it is very important to find alternative sources of decomposers derived from nature. This study aims to evaluate the quality of LOF made from RUW using local microorganism (LM) as a decomposer. A total of 3 types of decomposers are applied, namely: 1) feces extract (FE); 2) banana root extract (RBE) and 3) commercial decomposer (CD) as a control. The fermentation process was done for 4 weeks. As many as 3 types of aeration process time (APT) were applied, namely: 1) $0 \mathrm{~h}$; 2) $48 \mathrm{~h}$ and $96 \mathrm{~h}$. The results showed that the differences of $A P T$ resulted in $\mathrm{pH}$ values; C-Organic levels and $\mathrm{C} / \mathrm{N}$ ratio of $L O F$ from $L U K$ were different, whereas $\mathrm{N}$-organic and $\mathrm{P}_{2} \mathrm{O}_{5}$ levels were relatively constant. Different types of decomposers applied in the fermentation process yield different levels of $\mathrm{K}_{2} \mathrm{O}$, but the $\mathrm{pH}$ value, $\mathrm{C}$-Organic content, $\mathrm{C} / \mathrm{N}$ ratio and $\mathrm{P}_{2} \mathrm{O}_{5}$ were relatively constant. Performance of CD in LOF fermentation process was no different from FE and RBE performance. Application of both types of decomposers (FE and RBE)was equally potential to replace $\mathrm{CD}$ as a decomposer in the production process of LOF. Implementation of APT for $48 \mathrm{~h}$ was the best time process than others.

Key words: fermentation, local microorganism, organic fertilizer, rabbit's urine

سعد وآخرون

1003-990:49): 2018- مجلة العلوم الزراعية العراقية

تقييم جودة الأسمدة العضوية السائلة من نفايات الأرانب المخمرة باستخدام ميكرويات محلية كالمحلات

$$
\begin{aligned}
& \text { محمد عرفان سعد اسرياني سيتي نوراني سراج الدين أفندي أبوستم رمساني رشيد عبدالرزلق الطويل }
\end{aligned}
$$

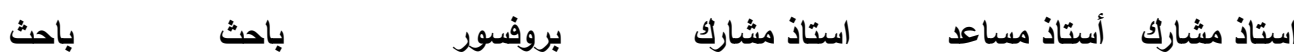

$$
\begin{aligned}
& \text { كلية علوم الحيوان ، جامعة حسن الدين ، جنوب سولاويزي ، إندونيسيا } \\
& \text { قسم علوم المحاصيل، كلية الزراعة، جامعة بوترا ماليزيا، سيلاتجور، ماليزيا }
\end{aligned}
$$

نفايات الأرانب في البول هي واحدة من المنتجات الثانوية لعملية استقلاب الأرانب التي لم يتم استخدامها. المحتوى المغذي المعقد في بول الأرانب هو إمكانات هائلة كمكون أساسي للأسمدة العضوية السائلة. في عملية الإنتاج من الاسمدة العضوية السائلة، تصبح عملية التخمير مهمة جدات في عملية فئية التخمير، فإن دور المُحلل مهم جداً. يصعب تنفيذ استخدام المحلات التجارية التي تحتوي على كائنات دقيقة مختارة في المناطق الريفية، لأنها مكلفة ويصعب الحصول عليها. لذلك، من المهم جداً إيجاد مصادر بديلة للمحلات المشتقة من الطبيعة. تهدف هذه الدراسة إلى تقييم جودة الاسمدة العضوية

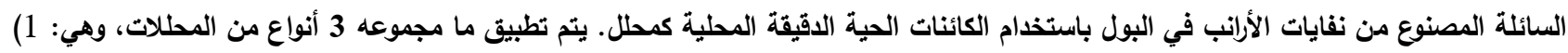

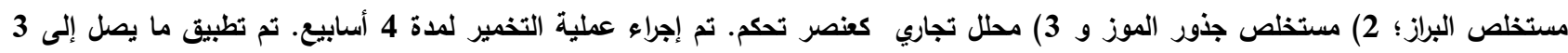

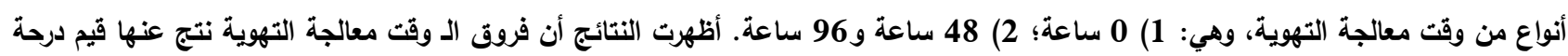
الحموضة ، مستويات الكريون العضوي ونسبة الكريون للنيتروجين من عملية التخمر من LUK كاتت مختلفة، في حين كانت مستويات النيتروجين العضوي و P205 ثابتة نسبياً. تتتج أنواع مختلفة من المُحلِّلات المستخدمة في عملية التخمير مستويات مختلفة من م2O م20، لكن قيمة درجة الحموضة، ومحتوى الكريون العضوي، ونسبة النيتروجين للكريون و P205 كانت ثابتة نسبيًا. أداء المحلل التجاري في عملية التخمير للأسمدة العضوية السائلة لا يختلف عن أداء مستخلص البراز ومستخلص جذور الموز. كان تطبيق كلا النوعين من المحلات (مستخلص البراز ومستخلص جذور الموز) على نفس القدر من القدرة على استبدال القرص المضغوط كلل في عملية إنتاج الأسمدة العضوية السائلة. كان تنفيذ وقت معالجة التهوية لمدة 48 ساعة أفضل عملية زمنية من غيرها.

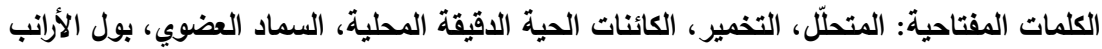




\section{INTRODUCTION}

The use of chemical fertilizers has become increasingly uncontrolled. This is certainly very dangerous to human health and the environment. Chemical fertilizers has been widely applied to increase agricultural production globally since the beginning of the green revolution (52)(30)(37). One characteristic of the high intensity of an agricultural ecosystem is the excessive use of chemical fertilizers, pesticides, and herbicides (18). In addition, some of them also have been using hormones (10) and microorganism (bacteria) (38) and fungi (54). The use of chemical fertilizers can directly improve yield (47). This is because the plants directly or indirectly will assimilate the nutrients provided by the inorganic fertilizer (3). However, on the other hand, the use of these chemicals has provided many negative effects on agricultural ecosystems (27). In general, the application of organic farming system will produce root system and improve the productivity of plant stems compared to agricultural systems that use chemical compounds (8)(14). The presence of mineral elements in fertilizers has played an important role in the success of agricultural production systems. Exponential growth in the human population continues to increase demand for biofuels and leads to ever-increasing demand for fertilizer. Despite the success of the current agricultural production system, excessive use of fertilizer has caused severe environmental problems and an increasing number of health problems (36)(1)(41). These effects are in the form of soil degradation, loss of plant genetic diversity, reduction of soil microbial diversity, groundwater source contamination and increased pollution (26)(11). Along with the development of livestock business, the livestock waste also become one of the pollutant factors. There are many organic ingredients contained in untreated livestock waste. The use of livestock waste as a raw material for fertilizer seems to be an alternative to increase the added value of the waste. Soil microorganisms play an important role in ecological functions such as nutrient cycles and the formation of soil aggregates through the decomposition of organic matter (49). Conditions of microbial ecosystems have an important role in soil stability. Microbes will affect the levels of denitrification, nitrification and nitrogen fixation processes (21)(39). Organic concept change with an-organic has a significant effect on soil microorganisms ecosystem condition (22). Changes in microbial activity and composition may affect plant growth. This occurs because of increased nutrient turnover and suppresses disease (58). Soil microbial biomass, activity and community structure are useful indicators of soil quality and health. This parameter is important in the change of agricultural land management practices (9). Therefore, adaptation processes, soil microbial structures are important for sustainable agricultural production processes (55). The soil in the organic farming regime has a more functional microbial diversity higher than conventional farming systems (33). The level of diversity of bacterial microorganisms is always higher in fertilizers than in processed farmlands regardless of land use patterns or seasons (19). Fertilizer can increase soil microbial activity and improve plant growth and prevent the development of pests and diseases. Compared with chemical fertilizers, livestock manure has been tested comprehensively and is determined as effectively in increasing the availability of nutrients in food crops, thereby increasing the yield of agriculture more efficiently and environmentally friendly (5)(31)(56)(53). The addition of livestock waste can increase the levels of organic matter and improve soil porosity, structural stability, moisture, and nutrient availability as well as biological activity. In the production process of liquid organic fertilizer (LOF), the role of decomposer is a . Decomposers involve the activity of microorganisms. The use of commercial decomposers should be considered, as they are expensive and difficult to obtain, especially farmers in rural areas. Therefore, it is necessary to develop a natural decomposer by utilizing local microorganism (LM). The LM is a number of microorganisms that develop on a particular substrate. The LM is a natural microorganism that grows and develops naturally in the environment and grown on a particular substrate. Source of LM can be derived from extracts of animal origin or a extracts from vegetable origin. The LM 
will then be applied in the fermentation process of LOF from Rabbit's urine waste (RUW) as a decomposer. The objective of this study was to evaluate the quality of LOF based on RUW utilizing LM as a decomposer.

\section{MATERIALS AND METHODS}

\section{Materials}

This study used the main ingredients of RUW local type. The RUW obtained from the rabbit local farm, in Sub-District Lalabata, Soppeng District, South Sulawesi Province, Indonesia. Decomposer type using feces extract (FE) from Bali cattle, and banana root extract (RBE) obtained from Makassar city, South Sulawesi Province. Commercial decomposer (CD) obtained from Songgo Langit Persada Ltd.Co. FE decomposer is a type of decomposer that uses local microorganisms from animal origin, while RBE uses a local vegetable substrate of vegetable origin. Other additional ingredients needed to produce liquid fertilizers are dolomite (lime farming) and brown sugar as the energy source of microorganism. The research equipment uses aerator (capacity 3L/min), fermentation container, hose, bottle, measuring cup (Pyrex), thermometer and $\mathrm{pH}$ meter (Hanna).

\section{Methods}

\section{Production process of FE decomposer}

A total of $1 \mathrm{~kg}$ of wet feces from Bali cattle mixed with $1 \mathrm{~kg}$ of brown sugar (ratio 1: 1). The mixture was supplemented with $500 \mathrm{~mL}$ of aquadest and then homogenized by using the mixer at $100 \mathrm{rpm}$ for $10 \mathrm{~min}$. The FE was subsequently fed into an anaerobic and natural fermented in the plastic container for 14 days

\section{Production process of RBE decomposer}

As much as $1 \mathrm{~kg}$ of root from local bananas, aged 2-3 years milled using a grinder to form a slurry. Furthermore, it is added to $100 \mathrm{~g}$ of brown sugar and $2 \mathrm{~L}$ of waste from rice washing process. The mixture was homogenized and subsequently inserted into a sealed plastic container. The fermentation process carried out on the an-anaerobic basis for 14 days

\section{Production process of LOF from RUW}

The production process of LOF from RUW by applying different decomposer was done based on the formula design in Table 1

Table 1. Design of materials composition of LOF from RUW that using different types of decomposers and APT (43)

\begin{tabular}{|c|c|c|c|c|c|c|c|c|c|}
\hline \multirow[b]{2}{*}{ Material Composition } & \multicolumn{9}{|c|}{ Decomposer Type } \\
\hline & FE-T $\mathbf{T}_{0}$ & $\begin{array}{l}\text { FE- } \\
\mathbf{T}_{48}\end{array}$ & $\begin{array}{l}\text { FE- } \\
T_{96}\end{array}$ & RBE-T ${ }_{0}$ & $\begin{array}{c}\text { RBE- } \\
\mathbf{T}_{48}\end{array}$ & $\begin{array}{c}\text { RBE- } \\
\text { T }_{96}\end{array}$ & $\begin{array}{c}\text { CD- } \\
T_{0}\end{array}$ & CD-T $_{48}$ & CD-T $_{96}$ \\
\hline $\begin{array}{l}\text { Urine from Bali Cattle } \\
\left.(\mathrm{L})^{* *}\right)\end{array}$ & 1 & 1 & 1 & 1 & 1 & 1 & 1 & 1 & 1 \\
\hline $\begin{array}{l}\text { Dolomite/Lime } \\
\text { Farming }(\%)(w / v) *)\end{array}$ & 0.9 & 0.9 & 0.9 & 0.9 & 0.9 & 0.9 & 0.9 & 0.9 & 0.9 \\
\hline $\begin{array}{l}\text { Brown Sugar } \quad(\%) \\
(\mathrm{w} / \mathrm{v}) *)\end{array}$ & 0.45 & 0.45 & 0.45 & 0.45 & 0.45 & 0.45 & 0.45 & 0.45 & 0.45 \\
\hline $\mathbf{F E}(\%) *)$ & 4.5 & 4.5 & 4.5 & - & - & - & - & - & - \\
\hline $\operatorname{RBE}(\%) *)$ & - & - & - & 4.5 & 4.5 & 4.5 & - & - & - \\
\hline $\mathrm{CD}(\%) *)$ & - & - & - & - & - & - & 4.5 & 4.5 & 4.5 \\
\hline
\end{tabular}

Note: $\mathrm{FE}=$ feces extract; $\mathrm{RBE}=$ root banana extract; $\mathrm{CD}=$ commercial decomposer ; aeration process time (APT) $\left(\mathrm{T}_{0}=0 \mathrm{~h} ; \mathrm{T}_{48}=48\right.$ $\left.\mathrm{h} ; \mathrm{T}_{96}=96 \mathrm{~h}\right) ; *$ ) percentage of ingredients calculated based on the amount of fermented urine $(* *)$ ). The mixing of materials for the production process of LOF was made based on the design of the formula in Table 1. Each of the decomposer/material mixtures was stirred to homogeneous and fed into the fermentation tube. The fermentation process was carried out on all tubes for 4 weeks at an-anaerobic room temperature. The APT was carried out according to each treatment

\section{Measurement and determination}

Analysis of pH (4). A total of $100 \mathrm{~mL}$ of LOF sample was put into a $100 \mathrm{~mL}$ shake bottle and $50 \mathrm{~mL}$ of ionized water was added. Bottle in shake using a shaker machine for $30 \mathrm{~min}$. $\mathrm{pH}$ meter calibrated using buffer $\mathrm{pH} 7.0$ and $\mathrm{pH}$ 4.0. The LOF suspension was then measured with $\mathrm{pH}$ meters

C-organic content (4). A total of $50 \mathrm{~mL}$ of LOF sample was put into a $100 \mathrm{~mL}$ measuring flask and then added with $5 \mathrm{~mL}$ of $2 \mathrm{~N}$ $\mathrm{K}_{2} \mathrm{Cr}_{2} \mathrm{O}_{7}$. To the flask was added $7 \mathrm{~mL}$ of $98 \%$ $\mathrm{H}_{2} \mathrm{SO}_{4}$ (p.a), shaken, then let stand for $30 \mathrm{~min}$. The standard solution of $250 \mathrm{ppm} \mathrm{C}$ was then prepared. A total of $5 \mathrm{~mL}$ of $5000 \mathrm{ppm}$ standard solution was introduced into a flask 
$100 \mathrm{~mL}$, furthermore, $5 \mathrm{~mL}$ of $\mathrm{H}_{2} \mathrm{SO}_{4}+7 \mathrm{~mL}$ of $2 \mathrm{~N}-\mathrm{K}_{2} \mathrm{Cr}_{2} \mathrm{O}_{7}$ solution as in a preceding manner was added. Blank was used as standard $0 \mathrm{ppm}$ C. Each was diluted with aqua dest. After a cold, $100 \mathrm{~mL}$ was shaken back and forth until homogeneous and then stored for 1 night. Further, measured by a spectrophotometer at a wavelength of $651 \mathrm{\eta m}$. The formula used is C-organic $(\%)=\mathrm{ppm}$ curve $\mathrm{x} 100 / \mathrm{mg}$ sample x Cf, where ppm curve $=$ standard regression curve; $\mathrm{Cf}=$ correction factor of water content $=100 /(100-\%$ of water content).

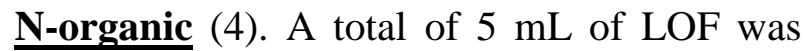
put into Kjeldahl's flask. Samples were added 0.25-0.50 g selenium mixture $+3 \mathrm{~mL} \mathrm{H}_{2} \mathrm{SO}_{4}$ (p.a) into the flask. The solution was shaken until homogeneous and left for 2-3 h. The solution was washed for 3-3.5 h on a hot plate with $150-350{ }^{\circ} \mathrm{C}$ gradually until a clear solution was obtained. The solution was then cooled and diluted to prevent crystallization. The solution was transferred quantitatively into a $250 \mathrm{~mL}$ of boiler distillation. Then, aquadest was added to half the volume of the boiling flask and a little boiling stone. The prepared distillate container was $10 \mathrm{~mL}$ of $1 \%$ boric acid in a $100 \mathrm{ml}$ volume Erlenmeyer spiked with, drops of Conway indicator. Distilled by adding $20 \mathrm{ml}$ of $40 \% \mathrm{NaOH}$. The distillation was complete when the volume of fluid in the Erlenmeyer has reached about 75 ml. Distillate was titrated with $0.05 \mathrm{~N}-\mathrm{H}_{2} \mathrm{SO}_{4}$, until the end point (the color of the solution changes from green to pink) (A) (mL), the determination of the blank was done $(B)(\mathrm{mL})$. Formula used, N-organic $=\mathrm{B}(\mathrm{mL})-\mathrm{A}(\mathrm{mL}) \mathrm{x}$ $\mathrm{N} \times \mathrm{NEW} /$ sample weight $(\mathrm{mg}) \times 100$, where, $\mathrm{NEW}=$ nitrogen equivalent weight

C/N Ratios (4). The $\mathrm{C} / \mathrm{N}$ ratio value was calculated by comparing the value of $\mathrm{C}$ organic with N-organic. Formula used, Ratio $\mathrm{C} / \mathrm{N}=\mathrm{C}$-organic value $/ \mathrm{N}$-organic value

$\underline{\mathbf{P}}_{2} \underline{\mathbf{O}}_{5}$ content (4). A total of $100 \mathrm{~mL}$ of LOF sample was inserted into a beker glass then heated. The precipitate was then filtered and washed with $3 \times 10 \mathrm{~mL}$ of hot aquadest. The filtrate was accommodated and supplemented with $10 \mathrm{~mL}$ of $2 \mathrm{M}-\mathrm{NH}_{4} \mathrm{Cl}$ and $10 \mathrm{~mL}$ of magnesia mixture. The cloudy solution was added 1:1 of $\mathrm{HCl}$ until dissolved. Further, added with the PP indicator and precipitated with $\mathrm{NH}_{4} \mathrm{OH}(1: 10)$ was excessive. The precipitate was cooled in ice and then filtered and washed with $\mathrm{NH}_{4} \mathrm{OH}(1: 20)$ to chloride free. The precipitate was then dried, incandescent and weighed until the weight was fixed. The result was then determined by the formula, $\mathrm{P}_{2} \mathrm{O}_{5}(\%)=\mathrm{Cf} \times \mathrm{Aw} / \mathrm{Sw} \times 100 \%$, where $\mathrm{Cf}=$ Correction factor $=\mathrm{Mr}$ of $\mathrm{P}_{2} \mathrm{O}_{5} /$ $\mathrm{Mr}$ of $\mathrm{MgP}_{2} \mathrm{O}_{5} ; \mathrm{Aw}=$ ash weight; $\mathrm{Sw}=$ sample weight; $\mathrm{Mr}=$ molecular relative

$\underline{\mathbf{K}}_{2} \underline{\mathrm{O} \text { content }}$ (4). Determination of $\mathrm{K}_{2} \mathrm{O}$ content using a flame photometer (Jenwey) tool with the P05-020A protocol (Bibby Scientific). A total of $2.5 \mathrm{~mL}$ of the LOF was inserted into $400 \mathrm{~mL}$ glass and added $125 \mathrm{~mL}$ of aquades and added with $50 \mathrm{~mL}$ of ammonium oxalate solution. The solution was heated for 30 minutes. The solution was then cooled and add a small amount of ammonium hydroxide solution. The solution was put into a $250 \mathrm{~mL}$ flask and diluted to a line mark. The solution was filtered by Whatman filter No. 30 into a $250 \mathrm{~mL}$ drying glass. A total of $25 \mathrm{~mL}$ of the solution was piped and put into a 500 $\mathrm{mL}$ pitcher and diluted with aquadest until the line marks. The solution was shaken until homogeneous. The solution was transferred to a $100 \mathrm{~mL}$ powder flask until it contains approximately $\mathrm{K}_{2} \mathrm{O}$ content of $16 \mathrm{ppm}$. The solution was diluted with aquades up to 100 $\mathrm{mL}$ and then stirred until homogeneous. Standard solutions were prepared with series containing 10,12,14,15,16,17, 18 and 20 ppm $\mathrm{K}_{2} \mathrm{O} \cdot \mathrm{K}_{2} \mathrm{O}$ content was determined by using flame photometer. The formula used, $\mathrm{K}_{2} \mathrm{O}(\%)=\mathrm{A} \times 20 / \mathrm{B}$, where $\mathrm{A}=\mathrm{ppm}_{2} \mathrm{O}$ in the sample solution; $\mathrm{B}=$ volume of titration $(\mathrm{mL})$

\section{Data analysis}

The data obtained were analyzed by means of a Completely Randomized Design (CRD) of factorial pattern with the aid of SPSS (oneway ANOVA) statistical program. The treatment showed a significant effect, then tested the real difference with Duncan'S Multiple Range Test (DMRT) at 5\% level (50).

\section{RESULTS AND DISCUSSION pH value}

The results of $\mathrm{pH}$ testing of LOF from RUW that produced by different APT and decomposer type were presented (Fig.1). The 
treatment differences were tested using Duncan's test. The results showed that the difference of APT significantly affects the $\mathrm{pH}$ value of LOF. The use of FE, RBE and CD (control) as decomposers was not significantly different $(\mathrm{P}>0.05)$ in APT. The performance of $\mathrm{FE}$ and $\mathrm{RBE}$ as decomposers was relatively similar to $\mathrm{CD}$ performance so that decomposers which were the source of local microorganisms can be applied in the liquid fertilizer production process. Based on the standard of regulation of the minister of agriculture, the Republic of Indonesia, that $\mathrm{pH}$ standard for liquid fertilizer was $4-9$, so the quality associated with the $\mathrm{pH}$ value can be said to have fulfilled. The $\mathrm{pH}$ value of liquid fertilizer made from rabbit urine produced close to the $\mathrm{pH}$ value of dairy cow urine used by (48) in the research was 7.8. The value of $\mathrm{pH}$ of LOF from RUW produced was also higher than liquid fertilizer by (42), was 5.455.64 that using 3 types of bio-activator $\left(\mathrm{EM}_{4}\right.$, boisca and shrimp paste). Microbes will work on neutral $\mathrm{pH}$ to acidic conditions ( $\mathrm{pH}$ 5.5-8). In the early stages of the decomposition process will form organic compounds. This condition will encourage the growth of bacteria and fungi. During the fermentation process, the organic acids will become neutral with a $\mathrm{pH}$ of 6-8. After the hydrolysis process, urine will have an optimal $\mathrm{pH}$ (8.5-10) (57).

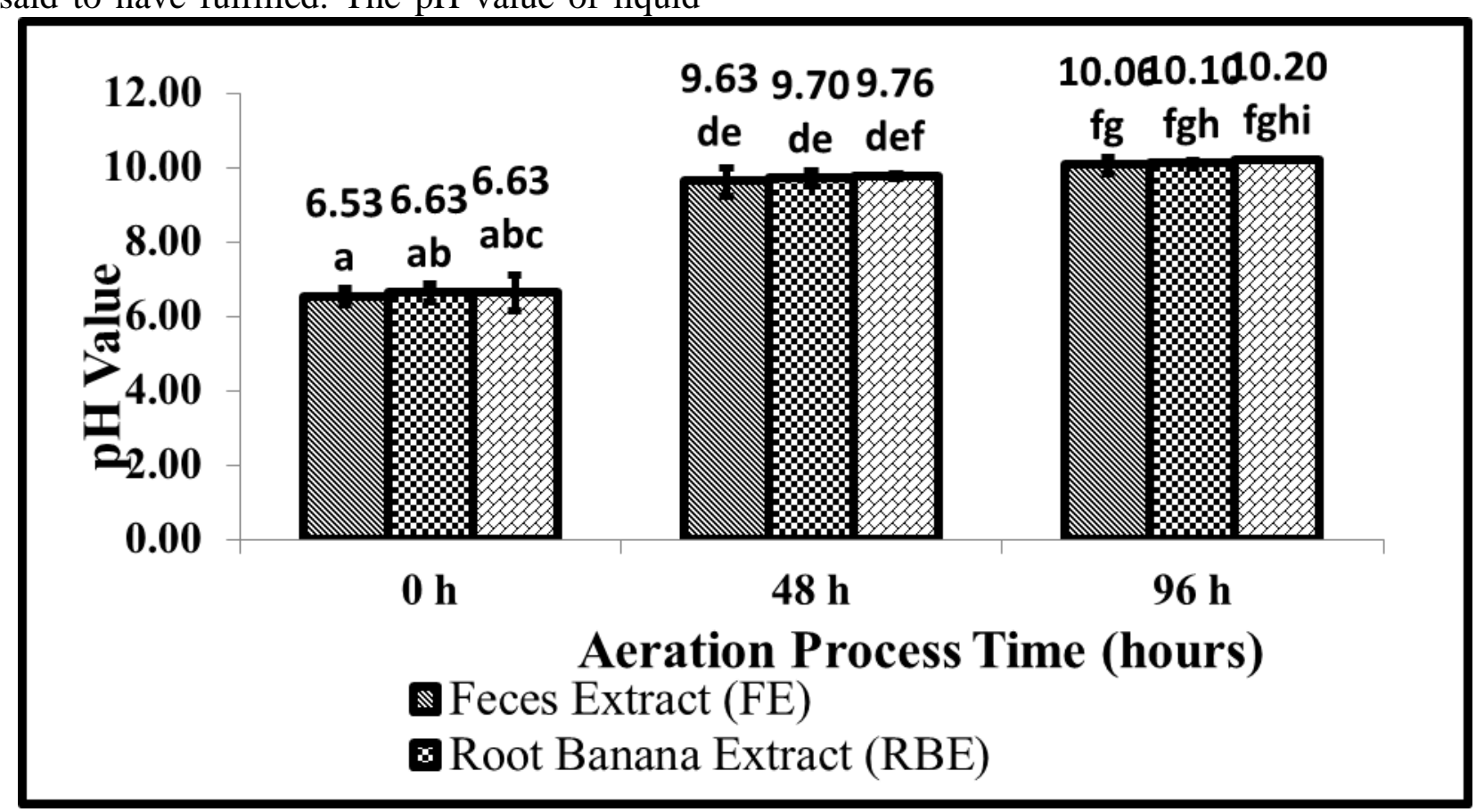

Fig 1. pH value of LOF from RUW produced using different APT and types of decomposer; ${ }^{\mathrm{a}}$

${ }^{i}$ Different superscripts showed significant differences $(P<0.05) ; F^{2}-T_{0}(6.53 \pm 0.21) ; F^{2}-T_{48}(9.63 \pm 0.38)$

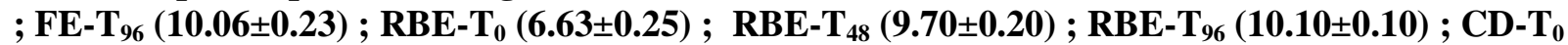
$(6.63 \pm 0.49) ; C D-T_{48}(9.76 \pm 0.06) ; C D-T_{96}(10.20 \pm 0.00)$; Feces Extract (FE) ; Root Banana Extract (RBE) ; Commercial Decomposer (CD); Liquid organic fertilizer (LOF); Rabbit's urine waste (RUW); Aeration process time (APT) ; $\mathrm{T}_{0}=\mathrm{APT} 0 \mathrm{~h} ; \mathrm{T}_{48}=\mathrm{APT} 48 \mathrm{~h} ; \mathrm{T}_{96}=\mathrm{APT} 96 \mathrm{~h} ;$; Comparative test using Duncan's multiple range test (DMRT).

\section{C-organic content}

Comparison of the C-organic content of LOF from RUW was presented (Fig.2). The result of the statistical analysis showed that the difference of APT significantly $(\mathrm{P}<0.05)$ differs on the level of C-organic of LOF from RUW. The different use of decomposer had no significant effect $(\mathrm{P}>0.05)$ at the level of $\mathrm{C}$ organic (Fig. 2). The use of LM sources from FE and RBE performance didn't different from $\mathrm{CD}$ performance. This shows that $\mathrm{FE}$ and $\mathrm{RBE}$ had the same ability in fermenting LOF. The FE and RBE were potentially used as decomposers to replace $\mathrm{CD}$. The content of $\mathrm{C}$ organic of LOF produced was higher than the result of LOF research by (35), i.e 0.67-0.86. This fertilizer used 3 types of bio-activators $\left(\mathrm{EM}_{4}\right.$, boisca and shrimp paste) in the fermentation process. C-organic is one indicator to determine the quality of a fertilizer (44). The results of (15) showed that the application of fertilizer from livestock can 
increase the level of C-organic to the soil by up to $18 \%$, especially on the surface layer. However, implementation errors, timing, and methods can lead to nutrient losses (nitrate leaching, and ammonia volatilization), increased soil salinity and pathogen migration and weeds. Level C-Organic urine produced higher than the results of research by (45) that was 0.62 in rabbit urine and 0.74 in cow urine. $\mathrm{C}$-organic content is a very important factor in organic fertilizer. C-organic content is what distinguishes with an-organic fertilizer. Organic fertilizer was aimed more at the content of C-organic or organic matter than its content. The value of $\mathrm{C}$-organic that is the differentiator with inorganic fertilizer. If the value of C-organic is low and not included in the provision of organic fertilizer then classified as an organic soil enhancer. Soil or soil enhancer ameliorant according to the provisions of the Indonesian Minister of Agriculture Regulation is synthetic or natural, organic or mineral materials. Organic matter acts as a "binder" of primary granules into secondary soil grains in the formation of a solid aggregate. This situation has great influence on porosity, storage and water supply, soil aeration, and soil temperature. Organic materials with high $\mathrm{C} / \mathrm{N}$ such as straw or husk have a greater effect on improving soil physical properties than with decomposed organic materials such as compost. Organic fertilizers/organic materials have important chemical functions such as (1) provision of macro-nutrients (N, P, K, Ca, $\mathrm{Mg}$, and $\mathrm{S}$ ) and such as $\mathrm{Zn}, \mathrm{Cu}, \mathrm{Mo}, \mathrm{Co}, \mathrm{B}, \mathrm{Mn}$, and $\mathrm{Fe}$, although the amount is relative. The use of organic materials can prevent the loss of micro-elements on marginal soil or land that has fewer with less balanced fertilization; (2) increase of land cation exchange (LCE); and (3) form anion capacity complex compounds with metal ions poisoning plants like $\mathrm{Al}, \mathrm{Fe}$, and $\mathrm{Mn}$. Increased C-organic by the application of inorganic nutrients leads to increased production of roots and higher air biomass to improve better plant productivity (24)(2).

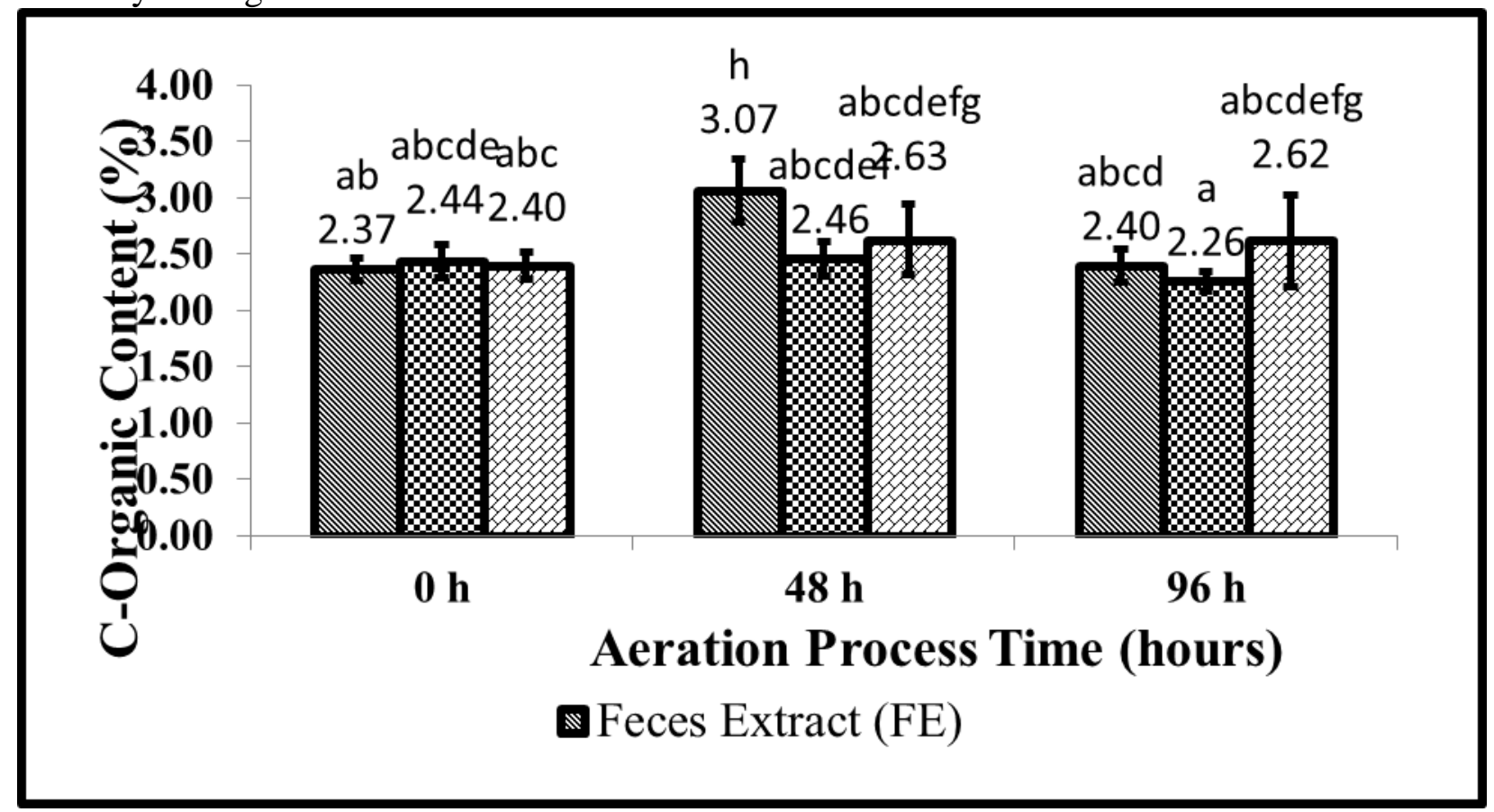

Fig 2. C-organik content of LOF from RUW produced using different APT and types of decomposer;

${ }^{a-h}$ Different superscripts showed significant differences $(P<0.05) ; F_{E}-T_{0}(2.37 \% \pm 0.10) ; F_{E}-T_{48}$

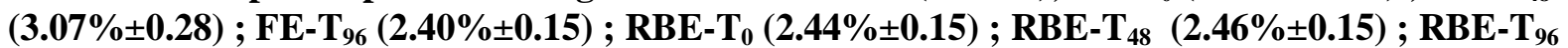
$(2.26 \% \pm 0.09) ; C^{-} D-T_{0}(2.40 \% \pm 0.12) ; C^{2}-T_{48}(2.63 \% \pm 0.31) ; C D-T_{96}(0.62 \% \pm 0.41) ;$ Feces Extract

(FE) ; Root Banana Extract (RBE) ; Commercial Decomposer (CD); Liquid organic fertilizer (LOF);

Rabbit's urine waste (RUW); Aeration process time (APT) ; $\mathrm{T}_{0}=\mathrm{APT} 0 \mathrm{~h} ; \mathrm{T}_{48}=\mathrm{APT} 48 \mathrm{~h}$; $\mathrm{T}_{96}=\mathrm{APT} 96$

$\mathrm{h}$; Comparative test using Duncan's multiple range test (DMRT).

N-organic content: The result of the test of the N-organic content of LOF from RUW was presented (Fig.3). The result of the statistical analysis showed that the difference of LM 
source as decomposer and APT had a significant effect $(\mathrm{P}<0.05)$ on $\mathrm{N}$-organic content (Fig.3). At the RBE, increase in fermentation time significantly increased the N-organic content of LOF. This is because with increasing APT, the activity of decomposer microorganism will increase to do fermentation activity. This results increased levels of $\mathrm{N}$-organic in the liquid fertilizer.

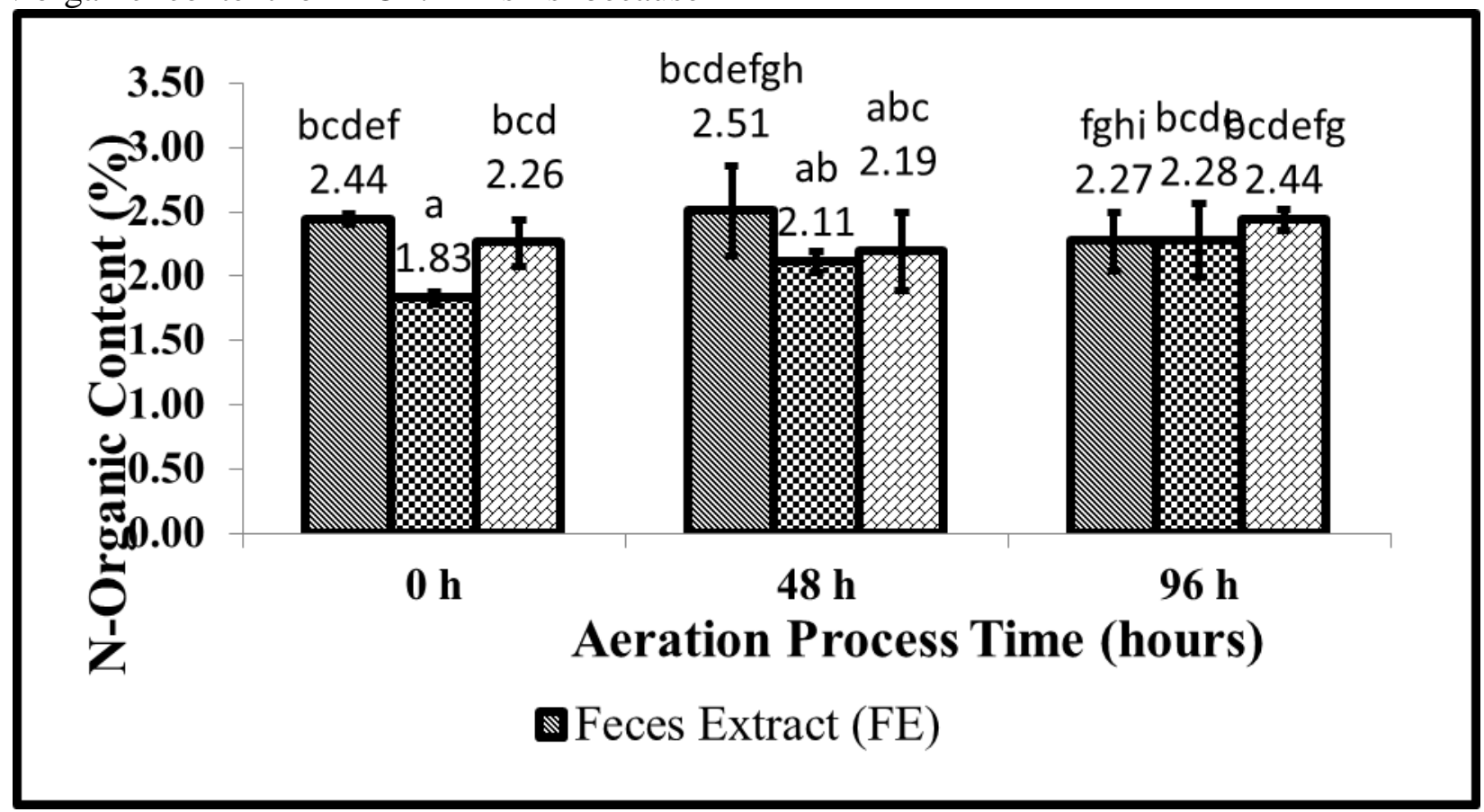

Fig 3. N-organik content of LOF from RUW produced using different APT and types of decomposer;

${ }^{\mathrm{a}-\mathrm{i}}$ Different superscripts showed significant differences $(\mathrm{P}<0.05) ; \mathrm{FE}-\mathrm{T}_{\mathbf{0}}(2.44 \% \pm 0.04) ; \mathrm{FE}^{-T_{48}}$

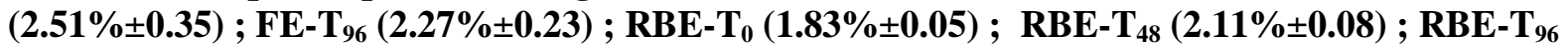
$(2.28 \% \pm 0.29) ; C D-T_{0}(2.26 \% \pm 0.18) ; C D-T_{48}(2.19 \% \pm 0.30) ; C D-T_{96}(2.44 \% \pm 0.08) ;$ Feces Extract (FE) ; Root Banana Extract (RBE) ; Commercial Decomposer (CD); Liquid organic fertilizer (LOF); Rabbit's urine waste (RUW); Aeration process time (APT) ; $\mathrm{T}_{0}=\mathrm{APT} 0 \mathrm{~h} ; \mathrm{T}_{48}=\mathrm{APT} 48 \mathrm{~h} ; \mathrm{T}_{96}=\mathrm{APT} 96$ h; Comparative test using Duncan's multiple range test (DMRT).

Based on these data it was show that the role of aerobic bacteria in the fermentation process is very large. Based on the data in Fig. 3 it can be seen that the N-organic content of the LOF using FE as decomposer was caused because, FE was derived from the feces of Bali cattle. Bali cattle's feces had high $\mathrm{N}$ levels as a result of the bacterial fermentation process that takes place in cattle rumen. In pastureland areas, cattle urine is one of the nitrogen sources in both $\mathrm{NO}_{3}{ }^{-}$and $\mathrm{N}_{2} \mathrm{O}$ emissions (46). Nitrogen element was required for plant growth in a pasture. Excess $\mathrm{N}$ levels can affect plant growth. Thus, $\mathrm{N}$ element is a limiting factor in an intensely managed grazing field (28). During the grazing process, livestock will contribute $\mathrm{N}$ derived from urine waste (13). This urine waste will certainly contribute $\mathrm{NO}_{3}{ }^{-}$ which greatly affects the diarrheal $\mathrm{N}$ composition (29). $\mathrm{N}$ requirements in a cattle grazing area need to be controlled to avoid damaging the ecosystem. One strategy to reduce the use of $\mathrm{N}$ on a pasture is to reduce the use of fertilizer applied to high $\mathrm{N}$ already derived soil from urine liquid fertilizer (16) (35). The deposition of urine to the soil can produce nitrous oxide emissions through the process of nitrification and microbial denitrification (7).

\section{$\mathrm{C} / \mathrm{N}$ ratio}

The value of $\mathrm{C} / \mathrm{N}$ ratio in LOF from RUW produced by decomposer type and different APT was presented (Fig.4). The result of the statistical analysis showed that the APT differs significantly $(\mathrm{P}<0.05)$ in $\mathrm{C} / \mathrm{N}$ value ratio, whereas the difference of decomposer type was not significantly different $(\mathrm{P}>0.05)$ (Fig.4). $\mathrm{C} / \mathrm{N}$ ratio is the ratio of the mass of carbon to the mass of nitrogen on a substance. 


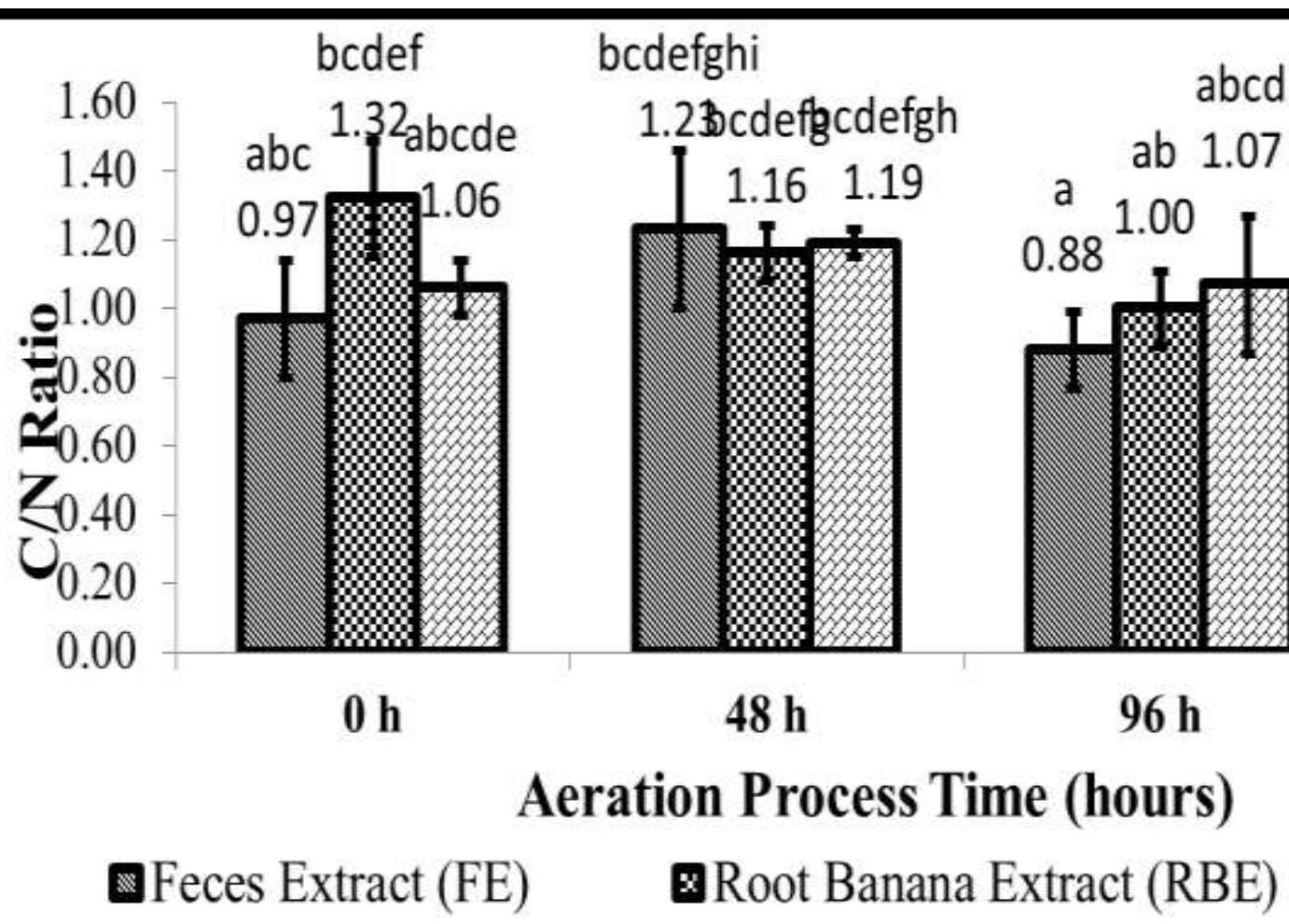

Fig 4. C/N ratio value of LOF from RUW produced using different APT and types of decomposer; ${ }^{\mathrm{a}-\mathrm{i}}$ Different superscripts showed significant differences $(\mathrm{P}<0.05) ; \mathrm{FE}-\mathrm{T}_{\mathbf{0}}$

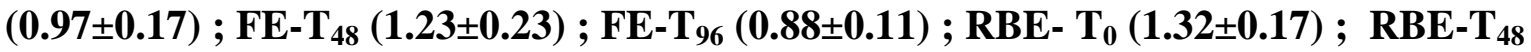
$(1.16 \pm 0.08) ; R^{2} B-T_{96}(1.00 \pm 0.11) ; C D-T_{0}(1.06 \pm 0.08) ; C D-T_{48}(1.19 \pm 0.04) ; C D-T_{96}$ (1.07 \pm 0.20$) ;$ Feces Extract (FE) ; Root Banana Extract (RBE) ; Commercial Decomposer (CD); Liquid organic fertilizer (LOF); Rabbit's urine waste (RUW); Aeration process time (APT) ; $\mathrm{T}_{0}=\mathrm{APT} 0 \mathrm{~h} ; \mathrm{T}_{48}=\mathrm{APT} 48 \mathrm{~h} ; \mathrm{T}_{96}=\mathrm{APT} 96 \mathrm{~h}$; Comparative test using Duncan's multiple range test (DMRT).

The $\mathrm{C} / \mathrm{N}$ ratio was used to study the presence of plants somewhere because nitrogen was absorbed by plants and microorganisms. Dead plants and microorganisms will leave behind carbon sediments. The magnitude of the difference between nitrogen and carbon will also distinguish the type of ecosystem that once was above (23). A higher $\mathrm{C} / \mathrm{N}$ ratio will cause the rate of fermentation in liquid fertilizers to decrease (40). Liquid fertilizer that has a higher $\mathrm{C} / \mathrm{N}$ ratio can cause the concentration of nitrogen in the soil is reduced because the activity of soil organisms tend to spend nitrogen for its growth. Organic compounds can directly affect groundwater conditions as well as the availability of $\mathrm{N}$ (32). The ability of soil in high root penetration causes the water binding capacity of the soil to be not optimal (51).

\section{$\mathbf{P}_{2} \mathbf{O}_{5}$ content}

Comparison of the $\mathrm{P}_{2} \mathrm{O}_{5}$ content of LOF from RUW at different APT and decomposer type was presented. The result of the statistical analysis showed that the difference between APT and type of decomposer did not affect the $\mathrm{P}_{2} \mathrm{O}_{5}$ level of LOF from RUW (P>0.05) (Fig. $5)$. 


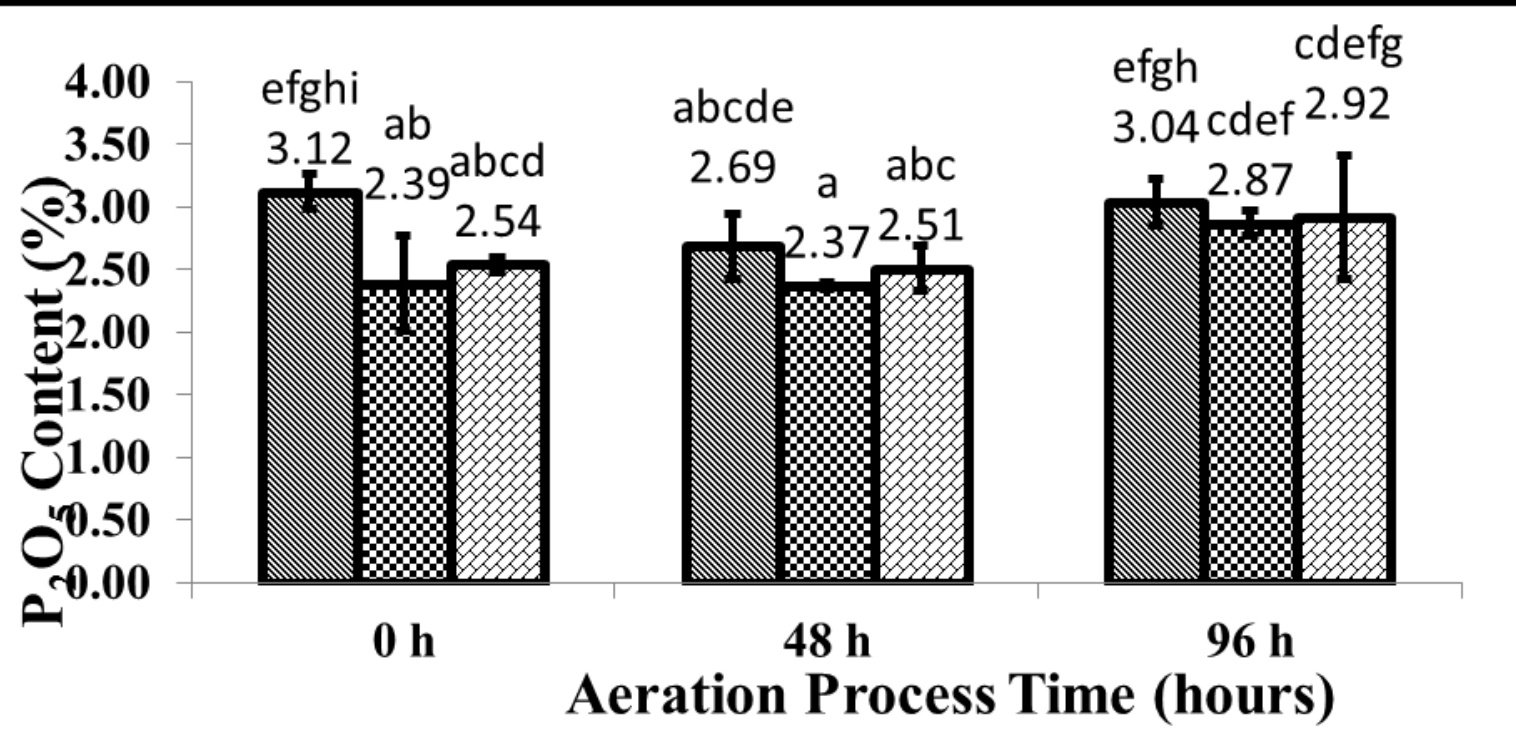

$\mathbb{N}$ Feces Extract $(\mathrm{FE})$

Fig 5. $\mathrm{P}_{2} \mathrm{O}_{5}$ content of LOF from RUW produced using different APT and types of decomposer; ${ }^{\mathrm{a}-\mathrm{i}}$ Different superscripts showed significant differences $(\mathrm{P}<0.05) ;$ FE- $_{0}$ $(3.12 \% \pm 0.14)$; FE-T $_{48}(2.69 \% \pm 0.26)$; FE-T $_{96}(3.04 \% \pm 0.19) ;$ RBE$^{2} \mathbf{T}_{0}(2.39 \% \pm 0.38)$; RBE$\mathrm{T}_{48}(2.37 \% \pm 0.03)$; RBE- $\mathrm{T}_{96}(2.87 \% \pm 0.10) ; \mathrm{CD}_{\mathbf{0}}(2.54 \% \pm 0.06) ; \mathrm{CD}_{\mathbf{0}} \mathrm{T}_{48}(2.51 \% \pm 0.18)$; CD-T $_{96}(2,92 \% \pm 0,49)$; Feces Extract (FE) ; Root Banana Extract (RBE) ; Commercial Decomposer (CD); Liquid organic fertilizer (LOF); Rabbit's urine waste (RUW); Aeration process time (APT) ; $\mathrm{T}_{0}=\mathrm{APT} 0 \mathrm{~h} ; \mathrm{T}_{48}=\mathrm{APT} 48 \mathrm{~h}$; $\mathrm{T}_{96}=\mathrm{APT} 96 \mathrm{~h}$; Comparative test using Duncan's multiple range test (DMRT).

Phosphates are a major source of potassium and nitrogen elements that are insoluble in water but can be treated to obtain phosphate products by adding acids. Commercially the phosphate compounds are marketed with various $\mathrm{P}_{2} \mathrm{O}_{5}$ content, i.e. 4-42\%. Meanwhile, the phosphate fertilizer test rate was determined by the amount of $\mathrm{N}$ (nitrogen), $\mathrm{P}$ (phosphate or $\mathrm{P}_{2} \mathrm{O}_{5}$ ), and $\mathrm{K}$ (liquid potassium or $\mathrm{K}_{2} \mathrm{O}$ ). Phosphate as a natural fertilizer is not suitable for food crops, because it is not soluble in water so it is difficult to be absorbed by the roots of food crops. Phosphate for food crop fertilizer needs to be processed into artificial fertilizer. Phosphorus elements can not be substituted from other resources so that the search for new resource resources is needed (6). Phosphorus elements should be sought to be moved from excess resources to less resources (17). Phosphorus is one of the most important element for living things. Phosphorus elements in addition to having benefits, also have a weakness when the amount is excessive. Excess phosphorus element in water will cause eutrophication so that phosphorus element is considered as a pollutant (12). Phosphorus is present in nature in two forms: organic phosphate compounds and inorganic phosphate compounds. Organic phosphate compounds are present in plants and animals, whereas inorganic phosphate compounds are present in water and soil where this phosphate dissolves the groundwater and seawater that are eroded and settled in the sediments. Phosphorus is also a limiting factor. Comparison of phosphorus with other elements in the aquatic ecosystem is smaller than in the body of living organisms. Phosphates are present in natural or waste water as orthophosphoric compounds, polyphosphates, and organic phosphates. Each phosphate compound is present in the form of dissolved, suspended or bonded within the cells of aquatic organisms. The presence of phosphate compounds in water greatly affects the balance of aquatic ecosystems. When the water phosphate levels are low $(<0.01 \mathrm{mg}$ $\mathrm{P} / \mathrm{L}$ ), alga growth will be blocked, this is called the oligotrophic. Conversely, when the water phosphate levels are high, plant growth and algae are not limited (eutrophic poverty). It can reduce the amount of oxygen dissolved 
in water. This is certainly very dangerous for the preservation of aquatic ecosystems

\section{$\mathrm{K}_{2} \mathrm{O}$ content}

The result of analysis related to $\mathrm{K}_{2} \mathrm{O}$ content in LOF from RUW produced using different APT and decomposer type was presented. The result of the statistical analysis showed that the difference of type of decomposer had a significant effect $(\mathrm{P}<0.05)$ on $\mathrm{K}_{2} \mathrm{O}$ content of LOF from RUW, but no significant effect on APT (P>0.05) (Fig. 6).

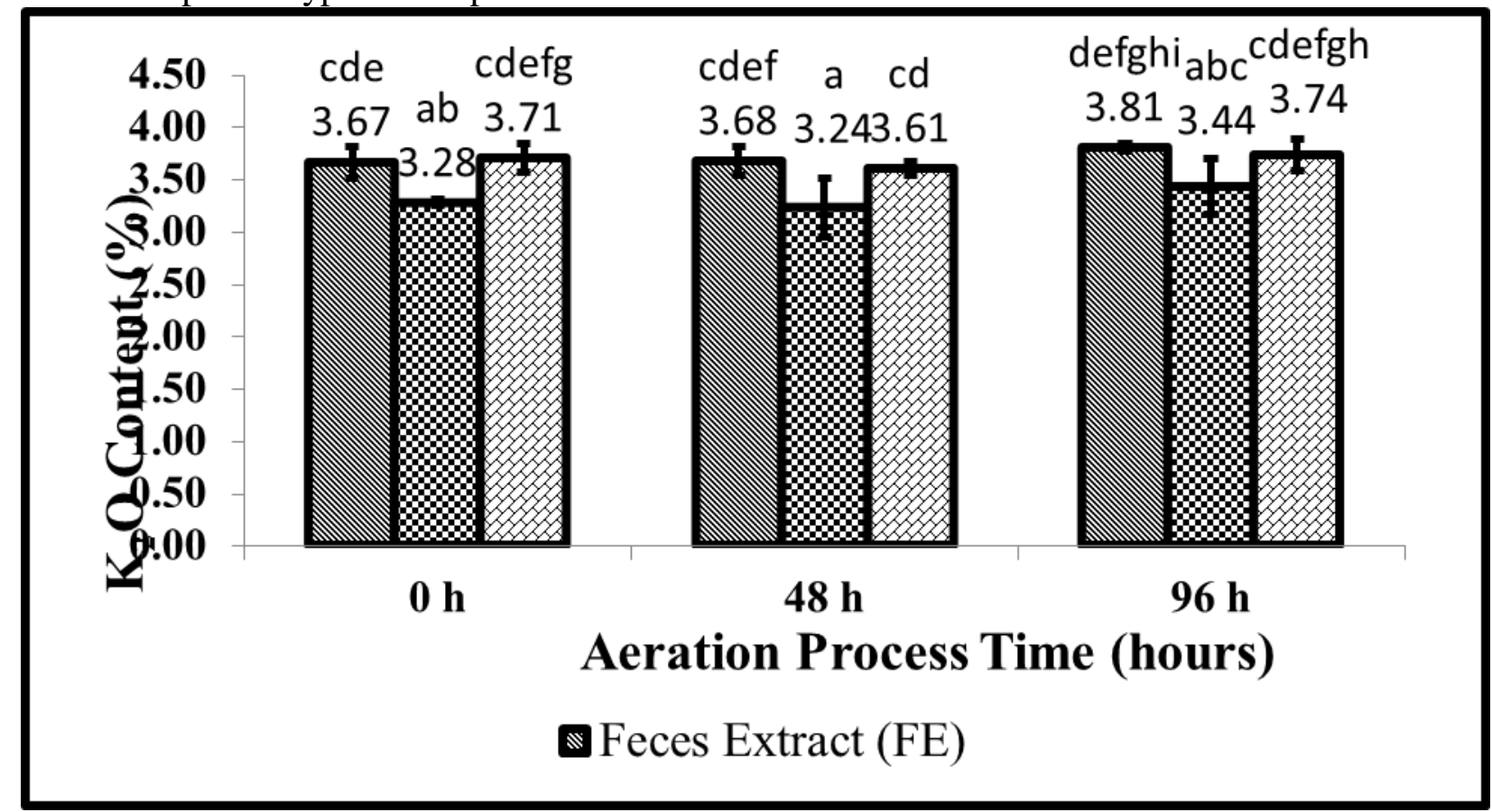

Fig 6. $\mathrm{K}_{2} \mathrm{O}$ content (\%) of LOF from RUW produced using different APT and types of decomposer; ${ }^{\mathrm{a}-\mathrm{i}}$ Different superscripts showed significant differences $(\mathrm{P}<0.05) ;$ FE- $_{\mathbf{0}}$ $(3.67 \% \pm 0.15)$; FE-T $_{48}(3.68 \% \pm 0.14)$; FE-T $_{96}(3.81 \% \pm 0.04)$; RBE-T $(3.28 \% \pm 0.03)$; RBE$\mathrm{T}_{48}(3.24 \% \pm 0.28) ; \mathrm{RBE} \mathrm{T}_{96}(3.44 \% \pm 0.27) ; \mathrm{CD}_{\mathbf{0}}(3.71 \% \pm 0.13) ; \mathrm{CD}_{\mathbf{0}}\left(\mathrm{T}_{48}(3.61 \% \pm 0.06)\right.$;

CD-T 96 (3.74\% \pm 0.15$)$; Feces Extract (FE) ; Root Banana Extract (RBE) ; Commercial Decomposer (CD); Liquid organic fertilizer (LOF); Rabbit's urine waste (RUW); Aeration process time (APT) ; $\mathrm{T}_{0}=\mathrm{APT} 0 \mathrm{~h} ; \mathrm{T}_{48}=\mathrm{APT} 48 \mathrm{~h} ; \mathrm{T}_{96}=\mathrm{APT} 96 \mathrm{~h}$; Comparative test using

\section{Duncan's multiple range test (DMRT)}

Currently, approximately $95 \%$ of potassium (K) was used in fertilizers. Crop production has increased dramatically above. The last few decades, largely due to the introduction of fertilizers that began in the mid-1900s. Test results of the $\mathrm{K}_{2} \mathrm{O}$ content of LOF from RUW were in the range of $3.24-3-81 \%$. This value is higher than the $\mathrm{K}_{2} \mathrm{O}$ content of LOF by (35), i.e. $0.47-0.59 \%$. The produced fertilizer uses 3 types of bio-activators (EM4, boisca and shrimp paste) in the fermentation process. Applications of $\mathrm{P}_{2} \mathrm{O}_{5}$ and $\mathrm{K}_{2} \mathrm{O}$ may not be required every year, depending on the specific amount available on the soil and the amount of $\mathrm{P}_{2} \mathrm{O}_{5}$ and $\mathrm{K}_{2} \mathrm{O}$ required to meet production targets for certain crops to be grown (34). The element of potassium is one of the main elements that make up $\mathrm{K}_{2} \mathrm{O}$ compounds. The $\mathrm{K}_{2} \mathrm{O}$ compounds play a role in the growth and strengthening of plants. The potassium element in the plant tissue is present in cationic form and varies from about 1.7 to $2.7 \%$ of the dry weight of the leaf that grows normally. The $\mathrm{K}^{+}$ion in the plant serves as an activator of many enzymes that participate in several major metabolic processes of plants. Potassium is used in the form of $\mathrm{K}_{2} \mathrm{O}$. In western Europe, potassium applications peaked in 1979. Since then experienced a decrease of $40 \%$ to 3.8 million tonnes per year (25). Potassium is vital in the process of photosynthesis. If $\mathrm{K}^{+}$ion deficiency then the process of photosynthesis will decrease, but the respiration of plants will increase. This incident will cause many of the carbohydrates present in the plant tissue to be used to obtain energy for its activities. This causes the process of formation of parts of the plant will be reduced which in the end the formation and production of plants will also be reduced. 
There are many studies that examine the effect of fertilizer doses on plant growth. However, do not consider the comparison of the type of fertilizer used. This is very important as a recommendation in the fertilization process, especially in new cultivars (20). Increased APT leads to an increase in $\mathrm{pH}$ value, $\mathrm{C}$ organic and $\mathrm{C} / \mathrm{N}$ ratio, whereas $\mathrm{N}$-organic and $\mathrm{P}_{2} \mathrm{O}_{5}$ levels were relatively constant. Different types of decomposers affect the $\mathrm{K}_{2} \mathrm{O}$ content of LOF products from RUW, but didn't affect $\mathrm{pH}$ values, $\mathrm{C}$-organic, $\mathrm{C} / \mathrm{N}$ ratio and $\mathrm{P}_{2} \mathrm{O}_{5}$. The $\mathrm{FE}$ and RBE decomposer types had the same performance as $\mathrm{CD}$. FE and RBE decomposer can be applied as a replacement $\mathrm{CD}$ in the production process of LOF from RUW. APT for $48 \mathrm{~h}$ was the best process time than others

\section{ACKNOWLEDGEMENTS}

The research team would like to thank the Ministry of Research, Technology and Higher Education of the Republic of Indonesia, the Head of Indonesian Institute of Sciences and the Rector of Hasanuddin University for the financing support through IPTEKDA LIPI Grants scheme of 2017. Thanks also to the student's team of St. Nur Azizah, Rudi Nal Adiatma and Vina Nur Isra for their assistance in laboratory and field research

\section{REFERENCES}

1. Abdel-Galil, A.G.M. 2015. Maximizing nitrogen uses in cotton wheat relay intercropping system in response to two wheat plant densities. Advances in Environmental Biology, 9(3): 502-511

2. Abustam, E., M.I.Said, and M.Yusuf. 2018. The effect of antioxidant activity of liquid smoke in feed supplement block on meat functional of muscle Longissimus dorsi. IOP Conf. Series: Earth and Environmental Science., 119:1-7

3. Agbede,T.M., S.O.Ojeniyi, and A.J.Adeyemo. 2008. Effect of poultry manure on soil physical and chemical properties, growth and grain yield of sorghum in Southwest, Nigeria. American-Eurasian Journal of Sustainable Agriculture, 2(1): 72-77 4. Agus, F. 2005. Petunjuk Teknis Analisis Kimia Tanah Tanaman Air dan Pupuk. Balai Penelitian Tanah, Bogor

5. Ahmad, R., G.Jilani, M.Arshad, Z.A.Zahir, and A.Khalid. 2007. Bio-conversion of organic wastes for their recycling in agriculture: an overview of perspectives and prospects. Ann Microbiol, 57: 471-479

6. Ashley, K., D.Cordell, and D.Mavinic. 2011. A brief history of phosphorus: from the philosopher's stone to nutrient recovery and reuse. Chemosphere, 84: 737-746

7. Barneze, A.S., A.M.Mazzetto, C.F.Zani, T.Misselbrook, and C.C.Cerri. 2014. Nitrous oxide emissions from soil due to urine deposition by grazing cattle in Brazil. Atmospheric Environment, 92: 394-397

8. Benchasri, S, and, S.Simla. 2017. Potential of chilli varieties under chemical and organic agricultural systems in Thailand. Bulg. J. Agric. Sci, 23(1): 58-70

9. Bending, G.D., M.K.Turner, and J.E. Jones. 2002. Interactions between crop residue and soil organic matter quality and the functional diversity of soil microbial communities. Soil Biol Biochem, 34: 10731082

10. Carraher, C.E Jr., M.S.Carraher, and H.H.Stewart. 2010. Metal-containing polymer structures for enhanced seed germination and plant growth. Advances in Environmental Biology, 4(1): 108-116

11. Chaudhry, A.N., G.Jilani, M.A.Khan, and T.Iqbal. 2009. Improved processing of poultry litter to reduce nitrate leaching and enhance its fertilizer quality. Asian J Chem, 21: 4997-5003.

12. Cordell, D., A.Rosemarin, J. J. Schröder and A.L. Smit. 2011. Towards global phosphorus security: a systems framework for phosphorus recovery and reuse options. Chemosphere, 4: 747-758.

13. Di, H.J. and K.C.Cameron, 2002. Nitrate leaching in temperate agroecosystems: sources, factors and mitigating strategies. Nutr. Cycl. Agroecosyst, 64: 237-256.

14. Domanska, K., T.Kijek and A.Nowak. 2014. Agricultural total factor productivity change and its determinants in European union countries. Bulg.J.Agric. Sci, 20(6): 12731280

15. Dordas, C.A., A.S.Lithourgidis, T.Matsi, and N.Barbayiannis. 2008. Application of liquid cattle manure and inorganic fertilizers affect dry matter nitrogen accumulation, and partitioning in maize. Nutr. Cycl. Agroecosyst, 80:283-296 
16.Draganova, I., I.Yule, M.Stevenson, and K.Betteridge, 2016. The effects of temporal and environmental factors on the urination behaviour of dairy cows using tracking and sensor technologies. Precision Agriculture, 17(4): 407-420.

17. Elser, J and E.Bennett. 2011. Phosphorus cycle: a broken biogeochemical cycle. Nature, 478: 29-31.

18. Farahani, G.H.N., Z.Zakaria, A. Kuntom, D.Omar, and B.S.Ismail. 2007. Adsorption and desorption of carbofuran in malaysian soils. Advances in Environmental Biology, 1(1): $20-26$

19. Ge,Y., J.B. Zhang, L.M. Zhang, M.Yang, and J.Z.He. 2008. Long-term fertilization regimes affect bacterial community structure and diversity of an agricultural soil in northern China. J. Soil Sediment, 8:43-50.

20. Henschke, M., E.Kozik, E.Wojciechowska, M.Kozlowska, A.Blaszyk, and K. Araszkiewicz, 2014. Influence of fertilizers of osmocote type and top-dressing onto the growth and nutrition state of carex comans berggr. 'Frosted curls'. Bulg. J. Agric. Sci, 20(4): 888-898

21. Hsu, S.F, and D. H. Buckley. 2008. Evidence for the functional significance of diazotroph community structure in soil. Int. Soc. for Microbiol. Eco. J, 3:124-136

22. Hu, J., X.Lin, J.Wang, J.Dai, and R. Chen. 2011. Microbial functional diversity, metabolic quotient, and invertase activity of a sandy loam soil as affected by long-term application of organic amendment and mineral fertilizer. J Soil Sediment, 11: 271280.

23. Ishiwatari, $\mathrm{R}$ and M.Uzaki. 1987. Diagenetic changes of lignin compounds in a more than 0.6 million-year-old lacustrine sediment (Lake Biwa, Japan). Geochimica Et Cosmochimica Acta, 51(2): 321-28

24. Izaurralde, R.C., W.B.McGill, and N.J.Rosenberg. 2000. Carbon cost of applying nitrogen fertilizer. Science, 288: 811-812

25.Johnston, A.E. 2003. Understanding Potassiumand and Its Use in Agriculture. European Fertilizer Manufacturers Association (EFMA). Belgium

26. Kaur, T., B.Brar, and N. Dhillon. 2008. Soil organic matter dynamics as affected by long-term use of organic and inorganic fertilizers under maize-wheat cropping system. Nutr Cycl Agroecosys, 81:59-69.

27. Kosolapova, A., V.Yamaltdinova, E.Mitrofanova, D.Fomin, and I.Teterlev. 2016. Yields of field crops and sod-podzolic soil fertility of West Ural depending on fertilizer system. Bulg. J. Agric. Sci, 22: 381-385

28. Lambert, M.G., D.A.Clark, and A.J.Litherland. 2004. Advances in pasture management for animal productivity and health. New Zealand Vet J, 52: 311-319.

29. Ledgard, S.F., J.W.Penno, and M.S.Sprosen, 1999. Nitrogen inputs and losses from clover/grass pastures grazed by dairy cows, as affected by nitrogen fertilizer application. J. Agric. Sci, 132: 215-225.

30. Leita, L., M. De-Nobili, C. Mondini, G. Muhlbachova, and L. Marchiol. 1999. Influence of inorganic and organic fertilization on soil microbial biomass, metabolic quotient and heavy metal bioavailability. Biol Fert Soils, 28: 371-376.

31. Leite, L.F.C., F.C.Oliveira, A.S.F.Araú jo, S.R. S.Galvão, and J.O.Lemos. 2010. Soil organic carbon and biological indicators in an Acrisol under tillage systems and organic management in north-eastern Brazil. Soil Res, 48: 258-265.

32. Lugo-Presez, J and J.E.Lloyd. 2009. Ecological Implications of organic mulches in arboriculture:a mechanistic pathway connecting the use of organic mulches with tree chemical defences. Arboriculture \& Urban Forestry, 35(4): 211-217

33. Mä-der, P., A.Fliessbac, D.Dubois, L.Gunstl, and P.Fried. 2002. Soil fertility and biodiversity in organic farming. Science, 296: 1694-1697.

34. Maguire, R., M.Alley, W.G.Wysor, and W.Flowers. 2009. Fertilizer Types and Calculating Application Rates. Virginia Cooperative Extension. Publication 424-035. Virginia State University

35. Moir, J.L., K.C.Cameron, and H.J.Di. 2007. Effects of the nitrification inhibitor dicyandiamide on soil mineral $\mathrm{N}$, pasture yield, nutrient uptake and pasture quality in a grazed pasture system. Soil Use Manage, 23: 111-120.

36. Morari, F., G.Vellidis, and P.Gay. 2011. Fertilizers, In Encyclopedia of Environmental 
Health, edited by J O Nriagu, Elsevier, Burlington, 727-737.

37. Naguib, N.Y.M. 2011. Organic vs chemical fertilization of medicinal plants: a concise review of researches. Advances in Environmental Biology, 5(2): 394-400

38. Ordookhani, K., S.Sharafzadeh, and M.Zare. 2011. Influence of PGPR on Growth, Essential Oil and Nutrients Uptake of Sweet Basil. Adv. Environ. Bio, 5(4): 672677

39. Philippot, L., J.Andert, C.M.Jones, D.Bru, and S. Hallin. 2011. Importance of denitrifiers lacking the genes encoding the nitrous oxide reductase for $\mathrm{N}_{2} \mathrm{O}$ emissions from soil. Global Change Biol, 17: 14971504.

40. Prahl, F.G., J.R.Ertel, M.A.Sparrow, and B.Eversmeyer. 1994. Terrestrial organiccarbon contributions to sediments on the washington margin. Geochimica Et Cosmochimica Acta, 58(14): 3035-48

41. Premsekhar, M, and V.Rajashree. 2009. Performance of hybrid tomato as influenced by foliar feeding of water soluble fertilizers. American-Eurasian Journal of Sustainable Agriculture, 3(1): 33-36

42. Raden, I., S.S.Fathillah, M.Fadli, and Suyadi. 2017. Nutrient content of liquid organic fertilizer (LOF) by various bioactivator and soaking time. Nusantara Bioscience, 9(2): 209-213.

43. Rasyid, R. 2017. Kualitas Pupuk Cair (Biourine) Kelinci yang Diproduksi Menggunakan Jenis Dekomposer dan Lama Proses Aerasi yang Berbeda. Skripsi. Fakultas Peternakan Universitas Hasanuddin, Makassar.

44. Reeves, D.W. 1997. The role of soil organic matter in maintaining soil quality in continuous cropping systems. Soil Till. Res, 43: 131-167.

45. Rosniawaty, S., R.Sudirja, dan H.Afrianto. 2015. Pemanfaatan urin kelinci dan urin sapi sebagai alternative pupuk organik cair pada pembibitan kakao (Theobroma cacao L). Jurnal Kultivasi, 14(1): 32-36

46. Roten, R.L., J. Fourie, J.L.Owens, J.A.K.Trethewey, D.C.Ekanayake, A.Werner, K.Irie, M.Hagedorn, and K.C.Cameron. 2017. Urine patch detection using LiDAR technology to improve nitrogen use efficiency in grazed pastures. Computers and Electronics in Agriculture, 135:128-133

47. Samanhudi, S., A.Yunus, B.Pujiasmanto, V.R.Cahyani, and D.S.Lestariana. 2017. The effect of arbuscular mycorrhiza and organic manure on soybean growth and nutrient content in Indonesia. Bulg. J. Agric. Sci, 23(4): 596-60310

48. Singh, J., A.Kunhikrishnan, N.S.Bolan, and S.Saggar. 2013. Impact of urease inhibitor on ammonia and nitrous oxide emissions from temperate pasture soil cores receiving urea fertilizer and cattle urine. Science of The Total Environment, 465: 5663.

49. Stark, C.H., L.M.Condron, M.O'Callaghan, A.Stewart, and H.J. Di. 2008. Differences in soil enzyme activities, microbial community structure and short-term nitrogen mineralisation resulting from farm management history and organic matter amendments. Soil Biol Biochem, 40: 13521363.

50. Steel, R.G.D and J.H.Torrie. 1991. Principle and Procedure of Statistics. $2^{\text {nd }} . e d$. International Book Company, Tokyo 51. Stefanou, S and A.Z.Papazafeiriou. 2014. The Effect of soil physical properties of an entisol on the growth of young poplar trees (Populus Sp.) Bulg. J. Agric. Sci, 20(4): 807812

52. Tilman, D. 1998. The greening of the green revolution. Nature, 396: 211-212.

53. Vasileva, V., T.Kertikov, and A.Ilieva. 2017. Dry mass yield and amount of fixed nitrogen in some forage legume crops after treatment with organic fertilizer Humustim. Bulg. J. Agric. Sci, 23 (5): 816-819

54. Wang, F.Y, and Z.Y.Shi. 2008. Biodiversity of Arbuscular Mycorrhizal Fungi in China: a Review. Advances in Environmental Biology, 2(1): 31-39

55. Wardle, D.A., G.W.Yeates, K.S.Nicholson, K.I.Bonner, and R.N.Watson. 1999. Response of soil microbial biomass dynamics, activity and plant litter decomposition to agricultural intensification over a seven-year period. Soil Biol Biochem, 31: 1707-1720.

56. Wildayana, E. 2017. Challenging constraints of livelihoods for farmers in the 
South Sumatra Peatlands, Indonesia. Bulg. J. Agric. Sci, 23 (6): 894-905

57. Zamora, P., T.Georgieva, A.Ter-Heijne, H.J.A.Tom, Sleutels, A.W.Jeremiasse, M.Saakes, C.J.N.Buisman, and P. Kuntke. 2017. Ammonia recovery from urine in a scaled-up microbial electrolysis cell. Journal of Power Sources, 356: 491-499

58. Zhang, Q.C., I.H.Shamsi, D.T.Xu, G.H.Wang, and X.Y.Lin. 2012. Chemical fertilizer and organic manure inputs in soil exhibit a vice versa pattern of microbial community structure. Appl Soil Ecol, 57: 1-8. 